The Philosophical Journal of Conflict and Violence

Vol. III, Issue 2/2019

(C) The Authors 2019

Available online at http://trivent-publishing.eu/

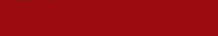

\title{
Dialectical Philosophy after Auschwitz Remaining Silent, Speaking Out, Engaging with the Victims
}

\author{
Andreas Herberg-Rothe \\ Fulda University of Applied Sciences, Germany \\ andreas.herberg-rothe@sk.hs-fulda.de
}

\begin{abstract}
Auschwitz, is still the greatest challenge for philosophy and reason, rather than representing their end, as Lyotard most prominently seems to imply. The article shows how the evolution of the question of dialectics from Hegel to postmodernism must be thought in relation to Auschwitz. The critics of reason and Hegel such as Lyotard, Derrida and Foucault are highlighting the break between reason and unspeakable suffering, for which Auschwitz is the most prominent symbol, but reintroduce 'behind' the scene much more speculative concepts than Hegel himself (Plasma by Lyotard, khora by Derrida and power as an absolute by Foucault). Adorno for his part thought that only a negative dialectics could address the problem adequately but transferred the unity of opposites just in the realm of utopia. But there is no negative (Adorno) or positive dialectics, only dialectics which mediates and posit the positive and the negative on a higher level.
\end{abstract}

Keywords: Auschwitz; New Dialectics; Lyotard; Hegel; Jonas; Adorno; Self-Transgression; Self-Preservation; Reason; Break between Reason and Suffering.

DOI: 10.22618/TP.PJCV.20204.1.201011

The PJCV Journal is published by Trivent Publishing

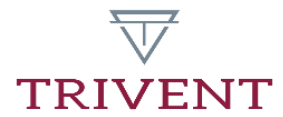

This is an Open Access article distributed in accordance with the Creative Commons Attribution Non Commercial (CC$B Y-N C-N D$ 4.0) license, which permits others to copy or share the article, provided original work is properly cited and that this is not done for commercial purposes. Users may not remix, transform, or build upon the material and may not distribute the modified material (bttp:/ / creativecommons.org/ licenses/by-nc/4.0/) 


\title{
Dialectical Philosophy after Auschwitz Remaining Silent, Speaking Out, Engaging with the Victims
}

\author{
Andreas Herberg-Rothe \\ Fulda University of Applied Sciences, Germany \\ andreas.herberg-rothe@sk.hs-fulda.de
}

\begin{abstract}
Auschwitz is still the greatest challenge for philosophy and reason, rather than representing their end, as Lyotard most prominently seems to imply. The article shows how the evolution of the question of dialectics from Hegel to postmodernism must be thought in relation to Auschwit:. The critics of reason and Hegel such as Lyotard, Derrida and Foucault are highlighting the break between reason and unspeakable suffering, for which Auschwitz is the most prominent symbol, but reintroduce 'behind' the scene much more speculative concepts than Hegel himself (Plasma by Lyotard, khora by Derrida and power as an absolute by Foucault). Adorno for his part thought that only a negative dialectics could address the problem adequately but transferred the unity of opposites just in the realm of utopia. But there is no negative (Adorno) or positive dialectics, only dialectics which mediates and posit the positive and the negative on a higher level.
\end{abstract}

Keywords: Auschwitz; New Dialectics; Lyotard; Hegel; Jonas; Adorno; Self-Transgression; Self-Preservation; Reason; Break between Reason and Suffering.

\section{Introduction}

"But no such miracle occurred; throughout the years of the Auschwitz slaughter, God remained silent."

Hans Jonas, Der Gottesbegriff nach Auschwitz

The current rising wave of anti-Semitism and racism around the world requires not only a new way of addressing the issue of Auschwitz, in view of the fact that these two phenomena are inextricably linked. It highlights most of all where racism and anti-Semitism are finally leading. It also questions our philosophical assumptions concerning the modern reductionism of philosophical reasoning to applying a method in the footsteps of Descartes and Kant, most visible in discourse ethics and simultenously those apparent solutions to highlight the difference between suffering and its articulation which in the end reinvent behind the scene new myths (Derrida, Lyotard, Agamben). But how can we meaningfully discuss Auschwitz without failing to address the suffering of the victims appropriately and without instrumentalizing Auschwitz for political purposes? Auschwitz is still the greatest challenge for philosophy and reason, rather than representing their end, as Lyotard most prominently seems to imply. Auschwitz signifies solely the end of a particular philosophical approach, that of the substitution of all content through a method, of discourse ethics and of concepts like post-modernity and constructivism. We owe it to the victims of the Holocaust to accept this 
challenge in the painful knowledge that we are always destined to fail, and in doing so accepting the whole extent of the consequences of our failure.

By turning to the sufferer in the full knowledge that we will always fail, we transcend the boundaries of our existence as well as the unspeakable experiences of suffering. But in our attempt to care for those who suffer especially in the knowledge that we will always fail, we transcend our own limitations and become true human. Acknowledging and at the same time transcending this gap and break (Sartre) between understanding, speaking and suffering constitutes a different kind of dialectics, different from that of Hegel, but also based on some of his basic assumptions.

The critics of reason and Hegel such as Lyotard, Derrida and Foucault are highlighting the break between language and suffering, but reintroduce 'behind' the scene much more speculative concepts than Hegel himself (Plasma by Lyotard, khora by Derrida and power as an absolute by Foucault until his Society Must be Defended). Adorno for his part thought that only a negative dialectics could address the problem adequately but transferred the unity of opposites just in the realm of utopia. There is no negative (Adorno) or positive dialectics, but only dialectics which mediates and posit the positive and the negative on a higher level. Only a real dialectical method is able to comprehend difference and unity, contrast and identity in dealing with speaking about the unspeakable. The difference is that other attempts which try to approach the problem of Auschwitz highlight the gap between reason and such unspeakable suffering but in the end reintroduce much more speculative concepts in order to overcome this gap either in mystificism (Plasma by Lyotard, khora by Derrida) or a metaphysics of the struggle and resistance (Baberowski, Agamben, the late Foucault). On the other side it is questionable whether those attempts to highlight the singularity of Auschwitz and the individuality of suffering must refrain from making general assessments. There seems to be an unbridgeable gap between expressing the suffering in language and thinking but by doing so failing to adequately representing it on one side and remaining silent, refraining from sharing terrible experiences because of the uniqueness of the suffering (see as outstanding examples the works of Primo Levi and Claude Lanzmann's film Shoab).

\section{Philosophy, God and Auschwitz}

In his speech delivered in Auschwitz, Pope Benedict XVI was able to combine two approaches to dealing with the subject of Auschwitz in an impressive manner: awareness akin to a confession of German guilt, as well as an engagement with the victims of the Holocaust on a personal level. ${ }^{1}$ But he made no progress to a new understanding of Auschwitz, even refrained from a theological interpretation, which draw criticism that he concealed the crimes of the ordinary Germans and turned them into victims of the Nazis too and also evaded the problem of anti-Semitism. Earlier approaches to 'understanding' Auschwitz revolved around the question of the relationship between modernity and the Holocaust (Bauman), the assumption of a fundamental 'rupture in civilization' (Dan Diner), and, of course, the theodicy problem. ${ }^{2}$ More recent approaches have questioned whether Kant's universality of the

\footnotetext{
1 Benedict XVI, Wo war Gott. Die Rede in Auschwitz.(Freiburg: Herder, 2006) ; Hans Jonas, Der Gottesbegriff nach Auschwit:. Eine jüdische Stimme (Frankfurt: Suhrkamp 1984).

2 Immanuel Kant defined the problem thus: "Unter einer Theodicee versteht man die Verteidigung der höchsten Weisheit des Welturhebers gegen die Anklage, welche die Vernunft aus dem Zweckwidrigen in der Welt gegen jene erhebt." ["By 'theodicy' we understand the defense of the highest wisdom of the creator against the charge which reason brings against it for whatever is counter-purposive in the world."'. At the same time, for Kant all philosophical attempts in theodicy seemed destined to fail. Our reason reaches its limits here. See Immanuel Kant, "Über das Mißlingen aller philosophischen Versuche in der Theodizee," in Zum ewigen
} 
individual, as well as the discourse and procedural ethics based upon it, are not indeed ineffective in relation to the Holocaust since they only establish a deviation from an ideal but fail to comprehend it fully as a challenge for their own approach as Zimmermann for example argues:

Nazism denies the Jews the right to exist and, by its exterminating strategies and practices, leaves the path of moral unity of the human species. No longer does mankind refer to all human beings but is split into those who are real humans and those who are not ... I propose the term 'rupture of species' [Gattungsbrucb] to characterize the radicalism of Nazism in moral terms. This term is meant to signify the overthrowing of traditional moral limits in order to transform mankind into a new world of moral otherness. ${ }^{3}$

In the end Auschwitz is questioning the crucial assumption of Kant and discourse theory that all humans share the same basic values and the same human moral. The critique of Zimmermann highlights the binary code between unity and difference concerning the question whether we humans as a species have the same or different moral values. Perhaps this is already the wrong question, because it implies a binary alternative, whereas a dialectical approach would argue that we share common values and at the same time they are distinct — in short, we comprehend and do not comprehend the suffering in Auschwitz.

But can we even truly understand and make sense of Auschwitz as a symbol of the Holocaust? Or do we ultimately trivialize the suffering of the victims if we claim to have understood Auschwitz and believe that in doing so we are doing justice to them? Or is there something about this crime against humanity that remains beyond comprehension? And what does this mean for philosophy beyond the binary opposition of universalism and relativism, of comprehension and incomprehension? These questions are at the center of Theodor W. Adorno's and Hans Jonas's analyses of the Holocaust, which I wish to re-examine with the help of a Hegelian paradigm. Here I am guided by an interpretation of Hegel that does not focus on the seclusiveness of Hegel's apparent system, but instead emphasizes his conception of an unending and open state of becoming, ${ }^{4}$ which can be visualized by a sinus curve erected on an enhancing x-axis. ${ }^{5}$

After the painful realization that anti-Semitism is once again spreading across right-wing, national and ethnic groups to Arab-Islamic movements and even among the educated middle classes, ${ }^{6}$ it is now time to revisit and re-examine the Shoah, the Holocaust. To the fore here are Adorno's statement that "to write poetry after Auschwitz is barbaric"7 and Hans Jonas's

Frieden und andere Schriften (Frankfurt: Suhrkamp, 2008). See also Benedict XVI, Wo war Gott. Die Rede in Auschwitz; Rolf Zimmermann, Pbilosopbie nach Auschwitz (Reinbek: Rowohlt, 2005).

3 Rolf Zimmermann, "National Socialism - Bolshevism - Universalism. Moral Transformations in History as a Problem in Ethics," in Nazi Ideology and Ethics, ed. Wolfgang Bialas \& Lothar Fritze (Cambridge: Cambridge Scholars Publishing, 2014), 392ff.

${ }^{4}$ See Andreas Herberg-Rothe, Lyotard und Hegel. Dialektik von Pbilosopbie und Politike (Vienna: Passagen, 2005).

${ }^{5}$ I have outlined this model of the philosophy of history in "Der Fortschritt im Bewusstsein, eine Menschheit als Ganzheit zu sein - Mit Hegel über Hegel hinaus denken," in Menschliche Höherentwicklung. Schriftenreibe "Die Psychogenese der Menschheit," ed. Gerd Jüttemann, Vol. VII. (Lengerich: Pabst Science Publishers, 2020), 133-144.

6 Felix Semmelroth, “Am besten wäre es, das Amt überflüssig zu machen,” hr-info (15.8.2018). This contribution can be heard at: www.hr-inforadio.de/programm/das-interview/antisemitismusbeauftragter-am-besten-waere-es-dasamt-ueberfluessig-zu-machen,semmelroth-108.html (Accessed June 27, 2019).

7 Theodor W. Adorno, Negative Dialectics (New York: Continuum Publishing, 1973). 
text on the concept of God after Auschwitz, which he subtitled "A Jewish Voice." co-authored the influential book Dialectic of Enlightenment, co-founded Frankfurt School of Critical Theory and was an idol of the student protest movement of 1968, which celebrates already more than its fiftieth anniversary. In which areas is Adorno right? In view of the suffering, in view of the deadly "processing" of millions of people implemented on an industrial scale, is silence only possible because every word uttered fails by such a huge degree to capture the monstrosity that occurred?

In Yad Vashem, the World Holocaust Remembrance Center in Jerusalem, like all other visitors I could only mourn in silence: "and no one dared, disturb the sound of silence" (Simon \& Garfunkel, who highlight that silence could be audible). The extent of the suffering is so immense that any expression of sympathy uttered falls far short of doing justice to this suffering. And then there is also the age-old question: does linguistic description and explanation always necessarily give meaning to something incomprehensible? What meaning can suffering then have? What is then the meaning of Auschwitz? These are nearly unbearable and even monstrous questions. The alternative would be that we are forced to face the conclusion that all suffering is meaningless? Is there thus an irremovable boundary between suffering and those who suffer, on the one hand, and its linguistic formulation, its articulation on the other? And vice versa, can anyone adequately express the extent of the suffering in linguistic terms?

The philosopher Ludwig Wittgenstein argued in a similar way that "the limits of my language are the limits of my world." Wittgenstein is part of a long tradition that attempts to replace the contradictions of natural languages with logically consistent languages. The paragon for this is the experience of the First World War, which in all its incomprehensibility did not end at Christmas 1914 as had been widely expected in Germany, but endured for a further four years and brought down the great empires (Germany, Austria-Hungary, the Ottoman Empire and the Russian Empire). Many at the time believed that no one could have wanted this war and that it had therefore arisen out of a misunderstanding. The advocates of logically consistent languages all believed that it was not possible to talk meaningfully about God, the infinite, the nation, the absolute, without this leading to misunderstandings, war and violence. How can we meaningfully talk about whether my God or yours is the right one? Wittgenstein said we should remain silent about the things we cannot talk about. According to him, the alternative would be to confront this conflict via the use of force as soon as the point is reached where we can no longer speak meaningfully. From this viewpoint, violence is the response when language fails. And for this reason alone, this position held that remaining silent about something was an appropriate strategy, in particular concerning the Absolute, God, Jesus, the Nation, that is, something about which we cannot speak logically.

What these approaches all share is the assumption that there are limits to language and logical systems that we either cannot cross without failing to do justice to suffering, or that this crossing of limits only leads to contradictions that ultimately can only be resolved through violence - this was the conclusion drawn from the experiences of the First World War.

But the French philosopher Jean Francois Lyotard, inventor of the concept of postmodernism, brought the problematic nature of silence to a head first through a critical reading of Heidegger and then Hegel. He criticized Heidegger for his "deafening silence" on Auschwitz: his philosophical texts, says Lyotard, in what they conceal, allow Heidegger's "profound and deliberate" compromise with National Socialism to come through loud and clear by his silence. They do so above all by "apart from one single sentence, remaining

\footnotetext{
${ }^{8}$ Hans Jonas, Der Gottesbegriff nach Auschwit: Eine jüdische Stimme (Frankfurt: Suhrkamp, 1984).

9 Ludwig Wittgenstein, Tractatus Logico-Philosophicus (Frankfurt am Main: Suhrkamp, 2001).
} 
entirely silent throughout on the topic of the extermination." 10 In contrast Lyotard criticizes Hegel for his approach to making sense of world history — this include making sense of evil and of suffering. Hegel had argued that the "real" is reasonable. In this argument, he was taking up Goethe's words: "[This is] Part of the Power that would Always wish Evil, and always works the Good." Lyotard however postulates that the Auschwitz "model" signaled an end to Hegel's dialectical thinking, the assumption that human history was progressing despite all the suffering. Hegel is the direct "antipode" of Lyotard, representing precisely someone from which Lyotard wants to set himself apart in terms of what Hegel says ("the real is reasonable") against the background of the unavailability of Auschwitz. In this point, Lyotard follows in Adorno's footsteps. Due to his explicit opposition to Hegel, he ignores how much he in turn actually converges with Hegel in his concept of plasma. ${ }^{11}$

Consequently, Lyotard, like nearly all great critics of Hegel, also unconsciously returns to a Hegelian tradition of thought, though in the mask of a myth. After consistently referencing Kant in his criticism of Hegel, Lyotard formulates, in his conception of "plasma," nothing other than a new variant of the Hegelian "magic formula" of "identity of identity and nonidentity." The analysis of the feeling of beauty should reveal a reflexive strength that one can represent as constitutive plasma. "This field is not visible — it provides visibility. I, who sees, do not see it. It lets me see. And thus, it constitutes me as a seeing subject." The mediation, the "argumentation," and the "logicality" would all result from the plasma. Hegel could not have better said it.

Lyotard admittedly replaces the term "plasma" with "passive synthesis," probably because the term "plasma" appeared too metaphysical even for him. He asserts that the basis of critical reasoning would be neither in logic nor in pragmatics or subjective evidence but rather in a "primal receptivity for the result, the factual." Without this absorption of the other, which is supposedly the mystery of criticism, there would be nothing to think of. The question of whether plasma or passive synthesis is the proper term or that of an ideal community of feelings is in no way vital. The one and only vital thing is that an equally indescribable and likewise active identity is premised ("It lets me see. And thus, it constitutes me as a seeing subject."), from which, furthermore, all development follows. Lyotard writes word-for-word: The mediation, the "argumentation," and the "logicality" would all result from the plasma. This identity incorporates all differences in itself in that it is itself the absolute difference. This is nevertheless not only speculative in the poor sense of "to speculate" but rather it methodologically conforms to Hegel's absolute difference. In Hegel's conception, this absolute difference is an identity that is only different from itself, exactly like Lyotard's plasma. $^{12}$

Even more problematic are the critics of reason based on contemporary cynicism with relation to reason (Sloterdijk does not comprehend that his critique of "cynical reason" is purely cynical at its core), who at best arrive at an absolute negative mystification of all law (Agamben in the footsteps of Carl Schmitt's state of emergency), or a negative anthropology of man (again Agamben and Baberowski's emphasis on violence). But because they all refer to the non-representability of suffering as such these theories ultimately end up aligning with Nietzsche (explicitely Zimmermann) and arrive at an absolutization of the struggle (Foucault in his Society Must be Defended). They show that the position of the inexplicability of suffering actually does address those who suffer, but that the price of this departure from reason is a metaphysics of struggle.

${ }^{10}$ Jean Francois Lyotard, Heidegger und die Juden (Vienna: Passagen, 1988), 65.

${ }^{11}$ See Andreas Herberg-Rothe, Lyotard und Hegel. Dialektik von Pbilosophie und Politik.

12 See Jean-François Lyotard, "Grundlagenkrise," Neue Hefte für Philosopbie (1986): 1-33. 


\section{Silence as a Sympathy or Concealment}

Lyotard, on the other hand, although criticizing all "grand narratives" is fully aware about formulating a "grand narrative" of his own ${ }^{13}$ - albeit a different one from that of modernism, socialism and communism. The possibility of applying the concept of the "grand narrative" to Lyotard himself arises from one of his assertions: he emphasizes that the only thing that is unquestionable is the proposition, because it is immediately presupposed. To doubt that one formulates propositions is in any case a proposition itself, which also applies to the conscious maintaining of silence. Wittgenstein's famous postulate - whereof one cannot speak, thereof one must be silent - presupposes a precise definition, namely in propositions, of that about which one must be silent. Thus, in Lyotard's concept, the silence about Auschwitz is itself a proposition about Auschwitz. In remaining silent about Auschwitz (and about suffering in general), we make a statement. Silence can therefore be both an expression of sympathy but, above all, also a form of concealment by which we leave the victims alone with their suffering.

Since the fall of the Iron Curtain and the dissolution of the seemingly real socialist states, Hegel has been largely replaced by Kant. This was mainly justified by the fact that socialism saw itself in the tradition of Hegel - because Marx regarded himself as his successor, Hegel was also buried along with Marx - wrongly, in my view. It was Hegel who had argued that what is real is reasonable - and so I would like to add that evil itself has no meaning of its own. Like many of the other critics of Hegel, Lyotard overlooks the fact that Hegel distinguishes between the actuality as the agent and the naked reality. Hegel's proposition simply states that reason is at work despite all senselessness, violence and cruelty, because the senseless remains historically limited, it does not transcend itself. Whereas Lyotard attempts, with a relative degree of success, to maintain his own interpretation floating somewhere between the unspeakable and the implicit discourse about the unspeakable, this performative contradiction comes to light in his assessment of Hegel's position in an overt and stark way, especially in the complete negation of Hegel - expressed quite clearly as the assertion that 'Auschwitz' as a totalizing historical symbol represents the end of Hegel's speculative philosophy. Lyotard employs the unspeakable of the Auschwitz model in order to use this unspeakable as a piece of evidence to substantiate his own discourse. There is a certain palpable tragic aspect, if not a full-on tragedy, when Lyotard discursively instrumentalizes the infinite suffering associated with Auschwitz as something unspeakable vis-à-vis Hegel, without even remotely realizing this obvious self-contradiction.

Even Adorno, who, out of his own overconfidence, generally never retracted a sentence he had uttered, was obliged to correct himself once in his life: "Perennial suffering has as much right to expression as a tortured man has to scream; hence it may have been wrong to say that after Auschwitz you could no longer write poems." ${ }^{14}$ We must not remain silent, because we must listen to the victims, give them a voice and a space — even, and especially, after Auschwitz, we must not remain silent. Had Adorno's original statement endured, the Nazis would have prevailed: their monstrous crime would be elevated to the status of the sublime (Lyotard), one which is no long able to be captured in language.

By contrast, in his lecture on the concept of God after Auschwitz, Hans Jonas impressively formulated not only these possibilities but also the limits of language. Faced with the shattering question of where God was in Auschwitz, he concludes by remarking that we are sitting at the throne of the Most High "in circles far and nigh and - 'stammering'." This makes it clear that Adorno's position, that there could no longer be any poetry after Auschwitz, was essentially a limiting of knowledge. Jonas himself had radically exposed the

\footnotetext{
13 See Jean-François Lyotard, Heidegger und die Juden.

14 See Theodor W. Adorno, Negative Dialectics.
} 
significance of Auschwitz for our knowledge of God in such a way that in its tripartite division into the ability to know God, his omnipotence, and his universal kindness, we would be obliged to surrender one of the three in order to preserve the other two. Paradigmatically, Jonas formulates the three possible philosophical answers to the Auschwitz problem: the limitations of human knowledge, the relativization of the absolute, and, finally, the good itself. Despite his concluding remarks, which imply a limitation of human reasoning, he essentially justifies an explanation of the silence of God in Auschwitz by abandoning the assumption of His omnipotence. ${ }^{15}$

Without explicitly stating this, Jonas thus develops a concept of God which is a continuation of the Hegelian determination of the Absolute: Jonas writes that "in the beginning" God was omnipotent that He contracted into Himself, thus creating the nothing and, out of this nothing, the world. For Hegel, nothingness is in no way emptiness - he instead shifts between an understanding of nothingness as indeterminate chaos (as described in the creation myth) and complete indeterminacy. ${ }^{16}$ Contrary to all Jewish tradition, in which he sees himself, Jonas argues that God has retreated from this world in order to liberate it. After this singular decision to set the world absolutely free from Himself, Jonas argues that God did not intervene in Auschwitz because he could not do so. He is aware that this stance is in conflict with the Jewish tradition — he makes this radical conclusion for himself because he believes that this is the only way he can maintain the two other dogmas of the fundamental ability to comprehend God and His unquestionable goodness.

This renunciation of the omnipotence of God leads to the conception of a God who is above all a becoming God, but also a God that suffers (feels the suffering of others) and cares for people. Since I am not a theologian, I do not want to, and cannot, discuss the religious implications of this position, or whether a Christian understanding would imply a different solution. I will therefore limit myself to a mere handful of thoughts on philosophy. Jonas himself speaks of the becoming God. This position corresponds to the predominant importance of becoming in Hegel's philosophy, especially the transition from being to nothing and harks back to the beginning of his monumental work with the modest and at the same time immodest title: Science of Logic. ${ }^{17}$ Hegel highlights the unity as well as the difference, even the conflict between Being and Non-Being/Nothing. ${ }^{18}$ Based on their unity as well as their difference, I conclude that we must differentiate between ontology (unity) and epistemology (difference). From an ontological point of view, we must understand the world as 'One' and thus remain monists. Vittorio Hoesle demonstrated convincingly that absolute truth does exist. ${ }^{19}$ However, what the advocates of ultimate justification could not explain is how we can depart from the assertion of absolute truth and arrive at empirically based truth. For epistemology, however, the Auschwitz model, as Lyotard calls it, dictates that we cannot go beyond dualism. We can have knowledge of the Absolute, on this point I agree with Jonas - but never absolutely or completely, otherwise we would position ourselves as absolute and in this sense Hegel also made his own statements absolute when, at the end of his life, he

\footnotetext{
${ }^{15}$ See Hans Jonas, Der Gottesbegriff nach Auschwitz: Eine jüdische Stimme.

${ }^{16}$ See Andreas Herberg Rothe \& Key-young Son, Order wars and floating balance. How the rising powers are reshaping our world view in the twenty-first century (New York: Routledge, 2018).

17 Georg Wilhelm Friedrich Hegel, Werke in 20 Bänden (Frankfurt am Main: Suhrkamp, 1969 et seqq.); Vol. 5, Wissenschaft der Logik. For my interpretation of Hegel, see "Die Absolutheit des "anderen" Werden. Mit Hegel gegen Hegel denken," Hegel Jabrbuch (2011): 230-248.

${ }^{18}$ See Andreas Herberg Rothe, Lyotard und Hegel. Dialektik von Pbilosophie und Politik; Andreas Herberg Rothe \& Key-young Son, Order wars and floating balance. How the rising powers are reshaping our world view in the twenty-first century.

19 Vittorio Hoesle, Die Krise der Gegenwart und die Verantwortung der Philosophie. Transzendentalpragmatik, Let:tbegründung (Munich: Beck, 1990).
} 
wrote in the preface to his Science of Logic that his work contained the thoughts of God prior to the creation of the world.

\section{Faith and Reason}

The possibly naive assumption is that if there is to be a full congruence between understanding and that which we understand, the knowledge of the Absolute itself must be absolute. Although I concur with Joseph Ratzinger's position that faith and reason must not contradict each other, I am guided by the more Protestant position that God's love and human reason cannot be identical, that God's love is higher than all human reason. The view that if God is absolute, He can also be pluralistic (the Trinity) is indeed persuasive (I owe this argument to Bernd Goebel). But we have to ask whether God as the Absolute can then also be self-contradictory — and in this sense, Hegel argues that only the spirit can "endure the contradiction." If, however, God must abide by the bivalent logic that excludes contradiction, we are back with Frege, Whitehead and Russell as well as Cantor and even the Vienna Circle.

The complete rejection of the Absolute and God, and their replacement with something finite, ultimately only leads to the absolutization of something finite, whether that is Secretary General Stalin or the Führer Adolf Hitler. But also, among the French post-structuralists, it leads to the replacement of the Absolute by a new Absolute, plasma (in the case of Lyotard), khora (Derrida) or power (Foucault).

Unlike Kant, I rely here on Hegel's assumption that we can indeed understand the Absolute, but never completely. My assumption is that in order to understand the Absolute we must always think through and understand this process of understanding, ${ }^{20}$ because this process is a part of the Absolute. In Vittorio Hoesle's position, to the contrary, it is necessary that he explicitly negates and rejects Hegel's conception of becoming at the beginning of logic in his own construction. ${ }^{21}$ From a dialectical viewpoint the "understanding of the Absolute" also necessarily includes the process of the "understanding" of the "understanding of the Absolute" etc. We can understand the absolute, but this knowledge itself cannot be absolute - otherwise we would put human knowledge in the place of God. Throughout the history of the three monotheistic religions, such attempts have time and again led to bloody and violent outbreaks. Even if we assume that God has completely revealed Himself to us human beings, this does not mean that we can understand Him completely in our limited lifetime. The implication is that the revelation of God is complete from a religious point of view, but the understanding of the revelation must always remain incomplete - otherwise we would be taking God's place ourselves.

Jonas himself becomes stuck at a binary explanation. In order to preserve the ability to understand God and his all-embracing goodness, he rejects the idea of omnipotence with good reasons, calling it a self-contradictory concept. ${ }^{22}$ However, what is problematic is the radical conclusion he derives from this, that God can no longer intervene at all in the world and that he has indeed completely retreated from the world. A different picture emerges when we think of all three concepts Jonas put forward as one unit, which although mutually dependent, at the same time limit each other. This would mean that the ability to understand of God is limited by his omnipotence, and vice versa. In philosophical terms, this means that we can neither position the Absolute in its absoluteness (as occurs in a condensed Hegel interpretation) nor reject it; instead, we must maintain it as a 'moment,' a tendency of reality. Eric Voegelin had already emphasized that the rejection of the Absolute only leads to the

\footnotetext{
${ }^{20}$ Vittorio Hoesle, Hegels System (Hamburg: Felix Meiner, 1988).

${ }^{21}$ Ibid.

22 See Hans Jonas, Der Gottesbegriff nach Auschwitz: Eine jüdische Stimme.
} 
formation of polytheistic substitute religions — whether they are "demigods" such as the Führer, Stalin, or the nation and the proletariat or even the party. ${ }^{23}$

\section{Auschwitz is the Greatest Challenge for Philosophy and Reason rather than Representing their End, as Lyotard has Implied}

What are the implications of this focus on becoming for the philosophy of language, Adorno's problem, and Wittgenstein's position that the limitations of my language set the limitations of my world? With the "Auschwitz" model, as Lyotard calls it, we must undoubtedly rethink the definition of language itself. Language is much more than just statements of complete understanding about truth and falsehood. As Aristotle had already emphasized, we can distinguish between good and evil with language ${ }^{24}$; based on my understanding of Sartre we need to take this further, stating that we must distinguish between good and evil. Perhaps language is even primarily a form of engaging with, caring for or considering others? With the awareness that no language can even remotely begin to express suffering, we sense this difference and transcend the limitations of our language vis-a-vis suffering and those who suffer - and also transcend our own limitations. In the Hegelian sense, language is the mediation, the "interstice" (Plato), ${ }^{25}$ the "in between" 26 of the comprehensible and the incomprehensible. Such a mediation presupposes the rediscovery of dialectics - a floating (Clausewitz) and developing (Hegel) balance (again Clausewitz) ${ }^{27}$ between the comprehensible and the incomprehensible. Auschwitz is neither the end of philosophy, nor of language, nor of Hegel, nor of poetry - it is instead its greatest challenge. We owe it to the victims of the Holocaust to accept this challenge in the painful knowledge that we are always destined to fail, and in doing so accepting the whole extent of the consequences of our failure. By turning to the sufferer in the full knowledge that we will always fail, we transcend our limitations. The lack of ability to solve the theodicy problem ${ }^{28}$ posited here, however, does not lead to relativism, but to turning our attention to those who are suffering, whereby we not only permanently transcend our limitations, but also those of philosophy. This does not imply proclaiming that suffering is the sole essence of humankind. In addition to transcending our limitations, there is also the "filling" of the individual and social space as well as our fellow human space within our limitations, thus the dialectic of self-preservation and self-transgression. ${ }^{29}$ Put simply, we need Kant to assure ourselves of our moral principles, while we need Hegel so that we do not stand by but instead turn our attention to the sufferer.

\footnotetext{
23 See Eric Voegelin, Modernity Without Restraint: The Political Religions, The New Science of Politics, and Science, Politics, and Gnosticism (Columbia: University of Missouri Press, 1999).

${ }^{24}$ See Aristotle, Politica (Oxford: Oxford University Press, 1963).

${ }^{25}$ I use this concept in the way Eric Voegelin has interpreted Plato. See Eric Voegelin, "Reason: The Classic Experience," in Published Essays, 1966-1985, vol. 12, ed. Ellis Sandoz (Baton Rouge: Louisiana State University Press, 1990), 289-90.

26 See Andreas Herberg Rothe \& Key-young Son, Order wars and floating balance. How the rising powers are reshaping our world view in the twenty-first century.

27 Originally, I developed the concept of a floating and progressing balance of contrasts in my interpretation of Clausewitz and used it in order to explain a new dialectics beyond Hegel in Clausewitz's puzzle. The political theory of war (Oxford: Oxford University Press, 2007). See also Andreas Herberg Rothe \& Key-young Son, Order wars and floating balance. How the rising powers are reshaping our world view in the twentyfirst century.

28 Norbert Hoerster, "Die Unlösbarkeit des Theodizee Problems," Theologie und Philosophie 60 (1985): 400-409.

29 See Andreas Herberg-Rothe, "Clausewitz's Theorie des Krieges zwischen Selbsterhaltung und Selbstentgrenzung," in Eskalation zum Äußersten? Girards Clausewitz interdisziplinär kommentiert, ed. Wilhelm Guggenberger and Wolfgang Palaver (Baden-Baden: Nomos, 2015), 59-80.
} 
But in our attempt to care for those who suffer especially in the knowledge that we will always fail, we transcend our own limitations and become true human. Acknowledging and at the same time transcending this gap and break (Sartre) between understanding and suffering constitutes a different kind of dialectics, different from that of Hegel, but also based on some of his basic assumptions. Such thinking with Hegel beyond Hegel enables the thinking of an inevitable dialectics in order to become true humans. Such a new dialectics, based on Clausewitz's concept of the dynamic relation of defense and offense, ${ }^{30}$ can be exemplified by the model of a sinus curve but erected on an enhancing $\mathrm{x}$-axis; such a model enables to illustrate a system which is simultaneously open (at the x-axis) and closed (at the y-axis) as well as it takes into account cyclical movement and progress. ${ }^{31}$ It implies thinking in categories of waves, circles and cycles instead of modern Western linear thinking ${ }^{32}$ of parts and particles. ${ }^{33}$ By summarizing it could be said that Auschwitz is fundamentally challenging our way of thinking - only a new dialectical method is able to comprehend unity as well as difference between the speakable and the unspeakable.

\section{Acknowledgements}

I would like to express my very grateful thanks to Gert Jüttemann, Phil Langer, Vittorio Hoesle and Bernd Göbel as well as to two unknown reviewers for their comments, encouragement and critique in conjunction with this publication. My appreciation deserves Ian McGarry, B.A. (Hons) for translating most parts of my originally German essay. Desirée Wolf was essential to amend the final version. In the end I'm dedicating this essay to my children, grandchildren and my wife, who are giving me hope and believe that love is transcending suffering.

Fulda, 23.11.2019.

\section{References}

Adorno, Theodor W. Negative Dialectics. New York: Continuum Publishing, 1973.

Agamben, Giorgio. Was von Auschwitz, bleibt. Das Archiv und der Zenge. Frankfurt: Suhrkamp 2003.

Aristotle. Politica. Oxford: Oxford University Press, 1963.

Baberowski, Jörg. Räume der Gewalt. Frankfurt: Fischer, 2018.

Bauman, Zygmunt. Modernity and the Holocaust. Cambridge: Polity Press, 1991.

Liquid Modernity. Cambridge: Polity Press, 2000.

Modernity and Ambivalence. Cambridge: Polity Press, 1991.

Benedikt XVI. Wo war Gott. Die Rede in Auschwitr. Freiburg: Herder, 2006

Derrida, Jacques. Khora. Vienna: Passagen, 2001.

Diner, Dan. Das Jabrbundert verstehen. Eine universalhistorische Deutung. Munich: Pantheon, 1999. Foucault, Michel. Society Must be Defended. London: Penguin, 2003.

\footnotetext{
${ }^{30}$ See Andreas Herberg-Rothe, Clausewitz's puzzle. The political theory of war.

31 Andreas Herberg-Rothe, "Billiard Games and concentric circles. In between plural hegemony and hegemonic pluralism," Key-note lecture at the $3^{\text {rd }}$ international conference of the Philippine International Studies Organization (Cebu, 10.11.2019), unpublished Manuscript.

${ }^{32}$ Ibid. See also Andreas Herberg Rothe \& Key-young Son, Order wars and floating balance. How the rising powers are reshaping our world view in the twenty-first century.

33 "We are already confronted with this kind of thinking in the most advanced version of military strategy, hybrid warfare, which is the creative combination of regular as well as irregular, linear as well as non-linear approaches." Johann Schmid, Helsinki, personal communication.
} 
Herberg-Rothe, Andreas. Lyotard und Hegel. Dialektik von Philosophie und Politik. Vienna:

Passagen, 2005.

Clausewitz's puzzle. The political theory of war. Oxford: Oxford University Press, 2007. . "Clausewitz's Theorie des Krieges zwischen Selbsterhaltung und

Selbstentgrenzung.” In Eskalation zum Äußersten? Girards Clausewitz interdisziplinär

kommentiert. Edited by Wilhelm Guggenberger and Wolfgang Palaver, 59-80. Baden-

Baden: Nomos, 2015.

. \& Son, Key-young. Order wars and floating balance. How the rising powers are reshaping our

world view in the twenty-first century. New York: Routledge, 2018.

"Billiard Games and concentric circles. In between plural hegemony and hegemonic

pluralism." Key-note lecture at the $3^{\text {rd }}$ international conference of the Philippine

International Studies Organization. Cebu 10.11.2019. Unpublished manuscript 2019.

"Der Fortschritt im Bewusstsein, eine Menschheit als Ganzheit zu sein - Mit Hegel

über Hegel hinaus denken. " In Menschliche Höherentwicklung. Schriftenreihe "Die Psychogenese der Menschheit." Edited by Gerd Jüttemann, Vol. VII. 133-14. Lengerich: Pabst Science Publishers, 2020.

Hoesle, Vittorio. Hegels System. Hamburg: Felix Meiner, 1988.

Die Krise der Gegenwart und die Verantwortung der Philosophie. Transzendentalpragmatik,

Letżtbegründung. Munich: Beck, 1990.

Jonas, Hans. Der Gottesbegriff nach Auschwitz. Eine jüdische Stimme. Frankfurt: Suhrkamp 1984.

Lanzmann, Claude. Shoah. The Complete Text Of The Acclaimed Holocaust Film. New York: Da

Capo Press, 1995.

Levi, Primo. Survival in Auschwitz. New York: Schuster\&Schuster 1995.

Lyotard, Jean-Francois. Der Widerstreit. Munich: Wilhelm Fink, 1987. Heidegger und die Juden. Vienna: Passagen, 1988.

. "Grundlagenkrise." Neue Hefte für Philosophie (1986): 1-33.

Sloterdijk, Peter. Critique of cynical reason. Minneapolis: University of Minnesota Press, 1988.

Voegelin, Eric. Modernity Without Restraint: The Political Religions, The New Science of Politics, and

Science, Politics, and Gnosticism. Columbia: University of Missouri Press, 1999.

Zimmermann, Rolf. Philosophie nach Auschwit:. Reinbek: Rowohlt, 2005. 2017.

Ankommen in der Republik: Thomas Mann, Nietzsche und die Demokratie. Freiburg: Alber,

. "National Socialism - Bolshevism - Universalism. Moral Transformations in

History as a Problem in Ethics.” In Nazi Ideology and Ethics. Edited by Wolfgang

Bialas \& Lothar Fritze, 389-422. Cambridge: Cambridge Scholars Publishing, 2014. 